\title{
Rhizosphere Streptomyces formulas as the biological control agent of phytopathogenic fungi Fusarium oxysporum and plant growth promoter of soybean
}

\author{
MAYA SARI ${ }^{1}$, ABDJAD ASIH NAWANGSIH ${ }^{2}$, ARIS TRI WAHYUDI ${ }^{1, \boldsymbol{v}}$ \\ ${ }^{1}$ Department of Biology, Faculty of Mathematics and Natural Sciences, Institut Pertanian Bogor. Jl. Agatis, Kampus IPB Dramaga, Bogor 16680, West \\ Java, Indonesia. Tel./fax.: +62-251-8622833, ”email: ariswa@ apps.ipb.ac.id \\ ${ }^{2}$ Department of Plant Protection, Faculty of Agriculture, Institut Pertanian Bogor. Jl. Meranti, Kampus IPB Dramaga, Bogor 16680, West Java, Indonesia
}

Manuscript received: 3 April 2021. Revision accepted: 2 May 2021.

\begin{abstract}
Sari M, Nawangsih AA, Wahyudi AT. 2021. Rhizosphere Streptomyces formulas as the biological control agent of phytopathogenic fungi Fusarium oxysporum and plant growth promoter of soybean. Biodiversitas 22: 3015-3023. Rhizosphere Streptomyces are considered as promising sources of plant growth-promoting rhizobacteria (PGPR) and biocontrol agents against pathogenic fungi, particularly Fusarium oxysporum causing root rot, cotyledon rot, hypocotyl rot, and stunted growth in soybean. Formulation of rhizosphere Streptomyces with appropriate carrier materials is necessary to facilitate storage and application in plants. This study aimed to develop a formulation of rhizosphere Streptomyces, apply the formula to control F. oxysporum, and promote soybean plant growth. Five Streptomyces isolates, i.e., Streptomyces panaciradicis ARK 13, Streptomyces tritolerans ARK 17, Streptomyces recifensis ARK 63, Streptomyces tendae ARK 91, and Streptomyces manipurensis ARK 94 were used in this study. All of the isolates could grow in potato broth, rice bran extract, and molasses as alternative media. The highest biomass produced from the molasses growth medium. All five isolates had antifungal activity against $F$. oxysporum with the inhibition percentage ranging from $41 \%$ to $76 \%$, and all of them were detected to have the ia $\mathrm{M}$ gene. Indole-3-acetic acid (IAA) hormone produced by these isolates were ranging from 8.99-15.14 mg L-1, with the phosphate solubilization index of 2.13-2.47. Five rhizosphere Streptomyces formulas with the main carrier of peat could maintain the viability with the population density of $10^{8} \mathrm{CFU} \mathrm{g}^{-1}$ for 8 weeks of storage at room temperature. Two formulas, F17 and F94, were the best formulas to control disease caused by $F$. oxysporum with disease suppression of $74 \%$ in sterile soil and $80-85 \%$ in non-sterile soil. Formula F17 and F94 significantly increased soybean growth in sterile and non-sterile soils. Therefore, these formulas could be recommended as biocontrol and plant growth promoters of soybean.
\end{abstract}

Keywords: Fusarium oxysporum, growth media, rhizosphere Streptomyces formula, soybean

\section{INTRODUCTION}

Soil-borne fungi, particularly Fusarium oxysporum, are pathogens causing diseases in soybean plants. This fungus attacks at the germination phase with rot symptoms in the roots, hypocotyl, and cotyledons, causing damping-off and stunted growth therefore failure to germinate (Arias et al. 2013; Arias et al. 2013; Cui et al. 2016). F. oxysporum has also been reported to attack legumes (Husnain et al. 2019), peanuts (Rajeswari 2015), and beans (Ellis et al. 2013). Soybean yields could decrease by $22 \mathrm{~kg} \mathrm{ha}^{-1}$ for every $1 \%$ increase of root rot disease caused by $F$. oxysporum (Maier et al. 2018).

Pathogenic fungi are generally controlled by synthetic fungicides. However, the use of synthetic fungicides results in environmental and health problems, and microbial resistance. An alternative solution for controlling pathogenic fungi is the use of Streptomyces bio-agents. Streptomyces is Gram-positive filamentous bacteria with high G-C content so that it is easier to colonize the substrate and more resistant to environmental changes (Olanrewaju et al. 2019). Streptomyces can be found in various environments, such as the plant rhizosphere as PGPR. The use of indigenous microorganisms was reported to be more effective as a biological control agent (Gopalakrishnan et al. 2011; Arora et al. 2016).

Twenty Streptomyces isolates from the soybean rhizosphere have been isolated in a previous study and characterized as having the ability as biocontrol and plant growth promoter agents (Mariastuti et al. 2018; Wahyudi et al. 2019). Streptomyces from the rhizosphere produced anti-fungal compounds that inhibit the growth of $F$. oxysporum in vitro, stimulate plant growth by producing the IAA hormone, solubilize phosphate, fix nitrogen, and increase the growth of soybean sprouts in vitro. Streptomyces from the rhizosphere could also produce siderophores, hydrogen cyanide, and various enzymes to degrade fungal cell walls (Glick et al. 2012; Sadeghi et al. 2012).

Five Streptomyces isolates from the rhizosphere, namely Streptomyces panaciradicis ARK 13, Streptomyces tritolerans ARK 17, Streptomyces recifensis ARK 63, Streptomyces tendae ARK 91, and Streptomyces manipurensis ARK 94 had the ability as biocontrol agents and plant growth promoters. The five potential isolates have the potential to be developed as a Streptomyces biocontrol formulation. Streptomyces biocontrol formulation is a combination of microbes with carrier 
materials (Gopalakrishnan et al. 2016). The Streptomyces formulation from rhizosphere with an appropriate carrier material aims to facilitate the application to plants, distribution, and storage. It is necessary to formulate Streptomyces from the rhizosphere with a carrier material that could support the viability of Streptomyces during its application on plant and storage. This study aimed to formulate biocontrol Streptomyces from rhizosphere with the main carrier of peat, apply the Streptomyces biocontrol formulas to control the phytopathogenic fungus $F$. oxysporum, and promote soybean plant growth.

\section{MATERIALS AND METHODS}

\section{Isolate preparation}

Five isolates Streptomyces ( $S$. panaciradicis ARK 13, S. tritolerans ARK 17, S. recifensis ARK 63, S. tendae ARK 91, and $S$. manipurensis ARK 94) from the soybean rhizosphere that has been previously isolated by Wahyudi et al. (2019) were used in this study. These isolates were re-cultured on ISP4 solid media (starch $10 \mathrm{~g},\left(\mathrm{NH}_{4}\right)_{2} \mathrm{SO}_{4} 2$ g, $\mathrm{CaCO}_{3} 2 \mathrm{~g}, \mathrm{~K}_{2} \mathrm{HPO}_{4} 1 \mathrm{~g}, \mathrm{Mg}_{2} \mathrm{SO}_{4} 1 \mathrm{~g}, \mathrm{NaCl} 1 \mathrm{~g}, \mathrm{Fe}_{2} \mathrm{SO}_{4}$ $0.001 \mathrm{mg}, \mathrm{MnCl}_{2} 0.001 \mathrm{mg}, \mathrm{ZnSO}_{4} 0.001 \mathrm{mg}$ in $1000 \mathrm{~mL}$ distilled water). Phytopathogenic fungus $F$. oxysporum was obtained from The Department of Plant Protection, IPB University. This fungus was re-cultured on potato dextrose agar (PDA) media for seven days.

\section{Optimization of Streptomyces growth media}

The alternative growth media for the production of Streptomyces cell biomass were potato broth (potato $200 \mathrm{~g}$ in $1000 \mathrm{~mL}$ distilled water), rice bran extract (rice bran 10 $\mathrm{g}$ in $1000 \mathrm{~mL}$ distilled water), and molasses (molasses $10 \mathrm{~g}$ and $3 \mathrm{~g}$ yeast extract in $1000 \mathrm{~mL}$ distilled water). Each Streptomyces isolate was grown on each sterilized solid growth media and incubated for seven days. Two plugs of Streptomyces from a solid growth medium were inoculated into $50 \mathrm{~mL}$ of liquid growth media. Nine tubes are provided for each liquid growth medium. After inoculation, tubes were incubated using a shaker at a speed of $100 \mathrm{rpm}$ $27^{\circ} \mathrm{C}$. Biomass of Streptomyces cells in each culture was harvested every day for nine days and centrifuged at 6000 rpm for 15 minutes at $27^{\circ} \mathrm{C}$. The supernatant was filtered using filter paper and the pellets were dried in an oven at $60^{\circ} \mathrm{C}$ for \pm 18 hours. The dry biomass of Streptomyces in each growth media was then weighed and compared. The growth media that are capable of producing high biomass weight were used as Streptomyces culture media for biocontrol formulations.

\section{Antifungal activity test}

The antifungal activity assay was carried out by the dual culture method (Khare et al. 2010). The Streptomyces isolates were grown on molasses as the best growth medium. Seven days old Streptomyces from molasses solid medium were scratched on a petri dish containing PDA medium with a distance of $3 \mathrm{~cm}$ from the center of the plate and incubated for 48 hours at $27^{\circ} \mathrm{C}$. The fungus $F$. oxysporum with a diameter of $8 \mathrm{~mm}$ from PDA medium was taken and placed in the center of the plate, facing Streptomyces isolates. Incubation was continued for seven days at $27^{\circ} \mathrm{C}$. The percentage of inhibition was calculated after seven days of incubation using the equation as follows:

$$
\text { Percentage of inhibition }(\%)=\frac{\mathrm{R} 1-\mathrm{R} 2}{\mathrm{R} 1}
$$

Where; $\mathrm{R}_{1}$ : growth radius of $F$. oxysporum in the negative control/without Streptomyces $(\mathrm{cm}), \mathrm{R}_{2}$ : growth radius of $F$. oxysporum on the opposite side of Streptomyces isolate $(\mathrm{cm})$

\section{Detection of iaa $\mathrm{M}$ gene in Streptomyces}

Five Streptomyces isolates were grown on a molasses solid medium for seven days. The Streptomyces DNA was extracted using The Genomic DNA Mini Kit. The DNA was amplified using a polymerase chain reaction (PCR). The size of the detected gene was 1698 base pairs, using primer iaaM_F (5'-ATG ACG TCC ACC GTG CCC AAC GCG-3') and iaaM_R (5'-CTA GTC CTC GGG GAG TTC CAC GGG-3'). The PCR condition was preceded by predenaturation $\left(94^{\circ} \mathrm{C}, 5\right.$ minutes $)$, denaturation $\left(95^{\circ} \mathrm{C}, 40\right.$ seconds), annealing $\left(59^{\circ} \mathrm{C}, 30\right.$ seconds), elongation $\left(72^{\circ} \mathrm{C}\right.$, 2 minutes), and post elongation $\left(72^{\circ} \mathrm{C}, 5\right.$ minutes) (Lin and $\mathrm{Xu}$ 2013). The PCR process was carried out for 27 cycles and ended with post PCR $\left(4^{\circ} \mathrm{C}, 5\right.$ minutes $)$. The amplification results were then sent to the sequencing service for similarity sequences. The search for similarity sequences was done using the Basic Local Alignment Search Tool (BLAST) program, available at the National Center for Biotechnology Information (NCBI).

\section{IAA production}

Measurement of IAA production was carried out using the colorimetric method (Khamna et al. 2010). Each isolate was cultured in $20 \mathrm{~mL}$ of molasses medium with the addition of $0.2 \mathrm{~mL}$ of L-tryptophan $0.2 \%$. The cultures were then incubated in a shaker incubator at $100 \mathrm{rpm} 27^{\circ} \mathrm{C}$ for eight days. After incubation complete, the culture was centrifuged at $11.000 \mathrm{ppm}, 4^{\circ} \mathrm{C}$ for 15 minutes. One $\mathrm{mL}$ of supernatant was taken from each culture and mixed with 4 $\mathrm{mL}$ of Salkowski reagent $\left(\mathrm{FeCl}_{3} \cdot 6 \mathrm{H}_{2} \mathrm{O} \quad 0.5 \% 7.5 \mathrm{~mL}\right.$ and $\mathrm{H}_{2} \mathrm{SO}_{4} 150 \mathrm{~mL}$ in $250 \mathrm{~mL}$ distilled water), then incubated in a dark room for 30 minutes. The absorbance of the mixture was measured using a Spectrometer at a wavelength of $520 \mathrm{~nm}$. The IAA concentration produced by each isolate was calculated by comparing the absorbance values on the IAA standard curve.

\section{Phosphate solubilization test}

The phosphate solubilization test was carried out by inoculating an agar plug ( $8 \mathrm{~mm}$ diameter) of seven days old Streptomyces on Pikovskaya medium (glucose $10 \mathrm{~g}$, $\mathrm{Ca}_{3}\left(\mathrm{PO}_{4}\right) 5 \mathrm{~g},\left(\mathrm{NH}_{4}\right)_{2} \mathrm{SO} 40.5 \mathrm{~g}, \mathrm{MgSO}_{4} \cdot 2 \mathrm{H}_{2} \mathrm{O} 0.1 \mathrm{~g}$, $\mathrm{MnSO}_{4} 0.1 \mathrm{~g}, \mathrm{FeSO}_{4} 0.1 \mathrm{~g}$, yeast extract $0.1 \mathrm{~g}$, and agar 15 $\mathrm{g}$ in $1000 \mathrm{~mL}$ distilled water), and then incubated for seven days at $27^{\circ} \mathrm{C}$. Streptomyces isolates that could form a clear zone indicate phosphate dissolving activity. The phosphate solubilization index then calculated using the equation as follows: 
The phosphate solubilization index $=\frac{\text { Colony diameter }+ \text { Clear zone diameter }}{\text { Colony diameter }}$

\section{Streptomyces formulation}

The formulation used is in the form of powder with the main carrier material is peat. It was obtained from The Indonesian Institute for Biotechnology and Bio-Nutrition Research, Bogor, West Java. The carrier material consisted of $85 \%$ peat, $10 \%$ rock phosphate, and $5 \% \mathrm{CaCO}_{3}$ that was packed into $10 \mathrm{~g}$ of heat-resistant plastic and sterilized twice using an autoclave. Streptomyces isolates were cultured on molasses medium for seven days. Five $\mathrm{mL}$ of Streptomyces culture $\left(10^{10} \mathrm{CFU} \mathrm{mL} \mathrm{m}^{-1}\right)$ was inoculated using a sterile syringe into $10 \mathrm{~g}$ of the sterile carrier material. The formulation was then incubated at room temperature $\left(27^{\circ} \mathrm{C}\right)$. The viability of Streptomyces in the formulation was observed using the Total Plate Count (TPC) method and the moisture content of each formulation was measured by comparing the wet and dry weights.

\section{Application of the formula on soybean plant}

The application of the biocontrol formulation on soybean plant was performed in several steps as described below.

\section{Experiment design in greenhouse}

The test of Streptomyces formula on soybean was performed at Cikabayan Experimental Garden, IPB University. The experimental design of the study was a Completely Randomized Design. There were 3 treatments, namely (i) seeds coated with Streptomyces formula, planted on sterile and non-sterile soil infested with $F$. oxysporum, (ii) seeds without Streptomyces formula coatings, planted on sterile and non-sterile soil infested with $F$. oxysporum (positive control), (iii) seeds without Streptomyces formula coatings, planted on sterile and non-sterile soil that was not infested with $F$. oxysporum (negative control). Each treatment has 3 replications and each replication consisting of ten soybean seeds.

\section{Soil preparation}

The soil composition used was ultisol soil, sand soil, and compost with a ratio of $2: 1: 1$. The soil treatment used was sterile and non-sterile soils. The soil sterilization was carried out twice using an autoclave. Sterile and non-sterile soils were then inserted into the treys ( 45 holes per trey).

\section{Preparation of the fungal pathogen $F$. oxysporum}

The fungal pathogen $F$. oxysporum was grown on PDA media for seven days. One plug $(8 \mathrm{~mm})$ of seven-day-old $F$. oxysporum was inoculated into $100 \mathrm{~mL}$ of potato dextrose broth (PDB) media. The cultures were incubated using a shaker incubator at $100 \mathrm{rpm} 27^{\circ} \mathrm{C}$ for seven days. The culture concentration was then determined by the TPC method. A total of $30 \mathrm{~mL}$ of $F$. oxysporum $\left(10^{3} \mathrm{CFU} \mathrm{mL} \mathrm{m}^{-1}\right)$ was infested into sterile and non-sterile soils in each trey hole.

\section{Preparation of soybean seeds}

The variety of soybean seeds used in this study was the Grobogan variety. Soybean seeds were surface sterilized by immersing the seeds in $96 \%$ ethanol for 5 minutes. The seeds were then soaked in $2.5 \% \mathrm{NaOCl}$ for 1 minute and rinsed ten times with sterile distilled water. Sterile seeds were soaked in sterile distilled water for 24 hours to accelerate germination. The seeds were then coated with each Streptomyces formula using the seed coating method and sown in $1 \mathrm{~cm}$ from the soil surface.

Observation of disease incidence and disease suppression

The observation of disease incidence and disease suppression in soybean was calculated after seven days of sowing. Symptoms of the disease observed were rot of root, hypocotyl, and cotyledon; stunted growth, and failure to germinate. The percentage of disease incidence was calculated using the equation:

Disease incidence $(\%)=\frac{\mathrm{n}}{\mathrm{N}} \times 100$

Where; n: number of symptomatic plants, $\mathrm{N}$ : total plants observed

The percentage of disease suppression was then calculated using the equation:

Disease suppression $(\%)=\frac{\left(\mathbf{X}-\mathbf{C}^{+}\right)}{\left(\mathbf{C}^{-}-\mathbf{C}^{+}\right)} \times 100$

Where; X: number of healthy plants in each treatment, $\mathrm{C}^{+}$: number of healthy plants in the non-coating treatment planted on soil infested with pathogenic fungi, $\mathrm{C}^{-}$: number of healthy plants in the non-coating treatment planted on soil that was not infested with pathogenic fungi

\section{Observation of plant growth}

The seven-day-old soybean plant was uprooted and cleaned from soil and dirt. Growth parameters observed were root length, plant length, wet weight, and dry weight. The dry weight was determined by drying the plants in an oven at $60^{\circ} \mathrm{C}$ for 24 hours.

\section{Data analysis}

Data on disease incidence, disease suppression, and growth promoters were statistically analyzed using oneway analysis of variance (ANOVA). The analysis was continued with the Tukey test with a confidence level of $95 \%$. All data were analyzed using the SPSS version 25 application.

\section{RESULTS AND DISCUSSION}

\section{Optimization of Streptomyces growth media}

Five Streptomyces isolates grew well on all types of solid growth media. The cell biomass of Streptomyces was varied in each growth medium (Figure 1). Molasses is the medium that produces the highest cell biomass of Streptomyces for five Streptomyces. The weight of cell biomass of $S$. recifensis ARK 63 in molasses medium was $2.94 \mathrm{mg} \mathrm{mL}^{-1}$ at seven days of incubation. 


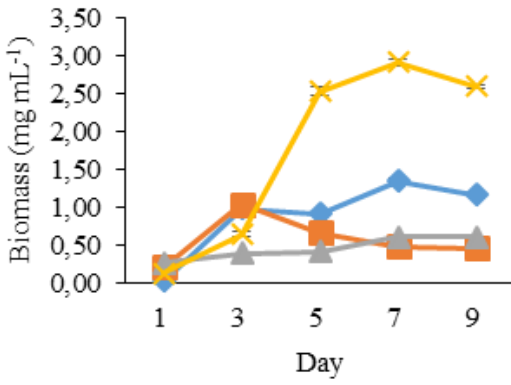

A

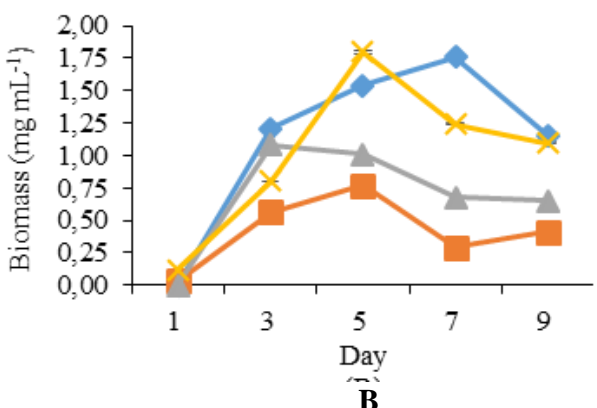

$\ddot{B}$

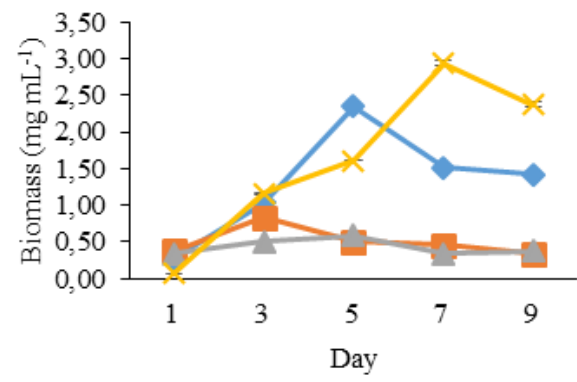

C

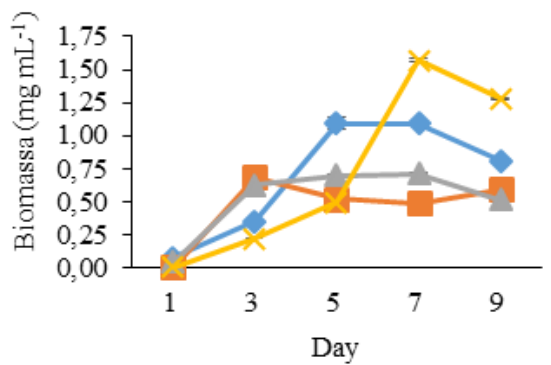

D

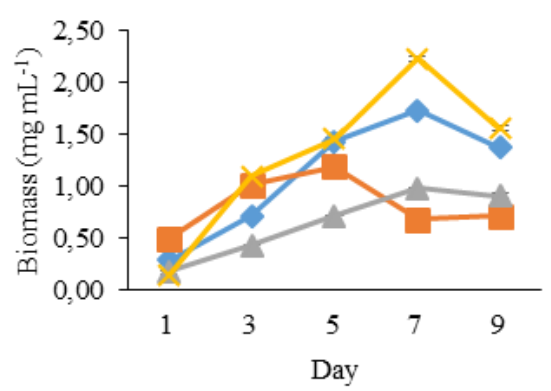

$\mathbf{E}$

Figure 1. The curves of Streptomyces biomass. A. S. panaciradicis ARK 13, B. S. tritolerans ARK 17, C. S. recifensis ARK 63, D. S. tendae ARK 91, and E. S. manipurensis ARK 94 on growth media of $(\rightarrow)$ ISP4, $(-\rightarrow)$ potato broth, $\left(-{ }^{-}\right)$bran extract, and (一) molasses

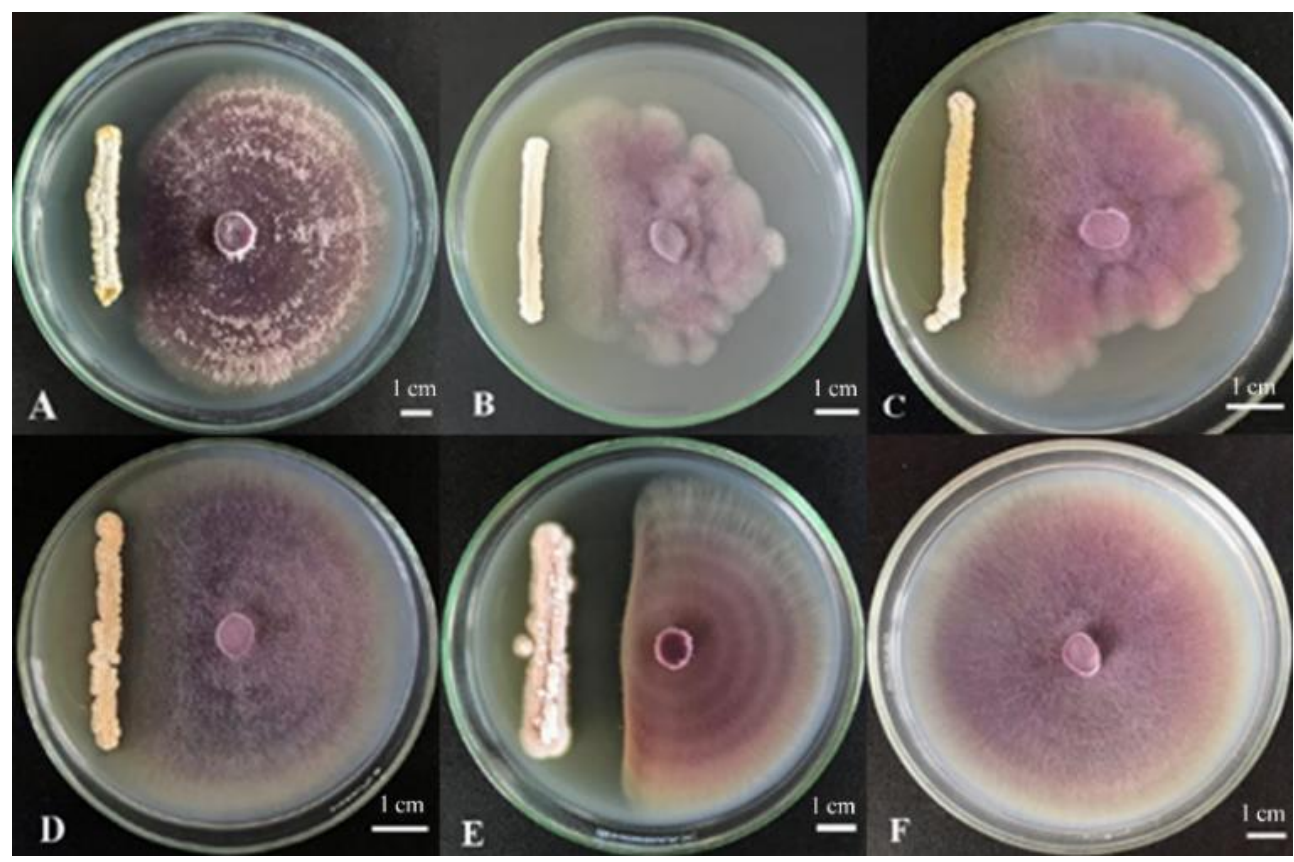

Figure 2. The growth inhibition of the pathogenic fungi $F$. oxysporum by Streptomyces isolates on PDA media after seven days incubation. A. S. panaciradicis ARK 13, B. S. tritolerans ARK 17, C. S. recifensis ARK 63, D. S. tendae ARK 91, E. S. manipurensis ARK 94, and F. control $F$. oxysporum.

\section{Antifungal activity}

The growth inhibition of $F$. oxysporum by five Streptomyces isolates was varied (Table 1). The highest inhibition after seven days of incubation was produced by S. manipurensis ARK 94, with an inhibition percentage of $76 \%$. The growth of $F$. oxysporum mycelium on the opposite of the Streptomyces isolates was inhibited compared to the growth of $F$. oxysporum mycelium on control (Figure 2). The growth inhibition of $F$. oxysporum might be due to the anti-fungal bioactive compounds produced by Streptomyces isolates. Microscopic observations were made on S. manipurensis ARK 94 as the 
best inhibitor of $F$. oxysporum mycelium growth. The morphology of hyphal $F$. oxysporum inhibited by $S$. manipurensis ARK 94 indicated hyphal lysis and granulation (Figure 3).

\section{Detection of iaaM gene in Streptomyces}

The amplification results using specific primers showed that the five Streptomyces isolates produced a target band measuring \pm 1698 bp (Figure 4). Based on the BLASTX analysis, the bands were identified as Tryptophan-2monooxygenase. Streptomyces spp. have varied similarity levels between $85.5 \%$ and $96.6 \%$ (Table 2). The phylogenetic tree was formed by the Neighbor-Joining method (Figure 5).

\section{IAA production}

Five Streptomyces isolates were able to produce IAA with varying concentrations of 8.99 to $15.14 \mathrm{mg} \mathrm{L}^{-1}$ (Table $3)$. The highest IAA concentration was produced by $S$. tendae ARK 91 isolates.

\section{Phosphate solubilization}

The ability to solubilize phosphate was characterized by the formation of a clear zone around the colony on Pikovskaya media. All of the isolates produced a clear zone around the colony and were able to solubilize phosphate with a phosphate solubilizing index of 2.13 to 2.47 (Table 4). The highest phosphate solubilizing index was produced by $S$. manipurensis ARK 94.

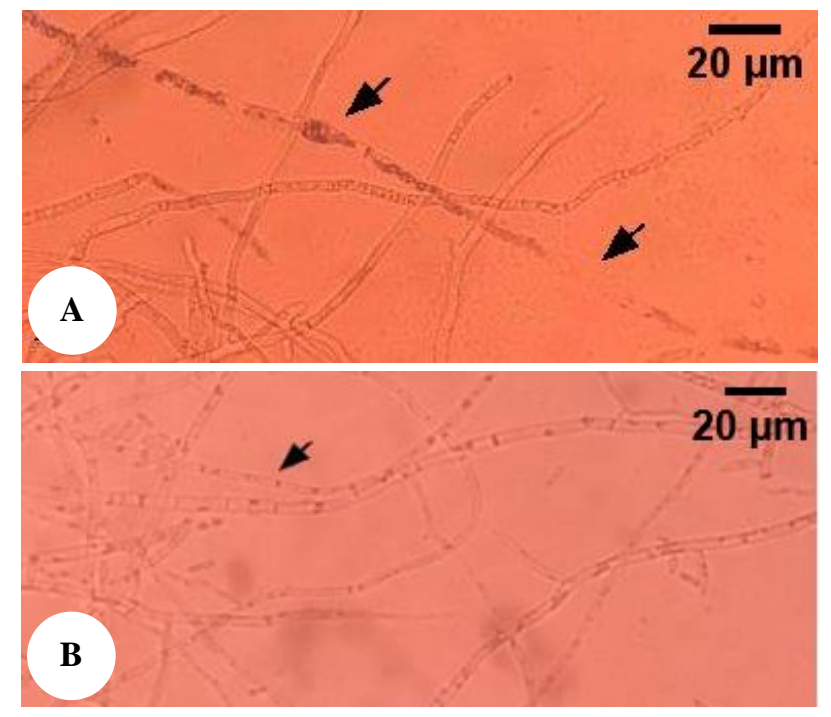

Figure 3. A. Morphology of $F$. oxysporum hyphae against $S$. manipurensis ARK 94, B. Normal hyphae of $F$. oxysporum

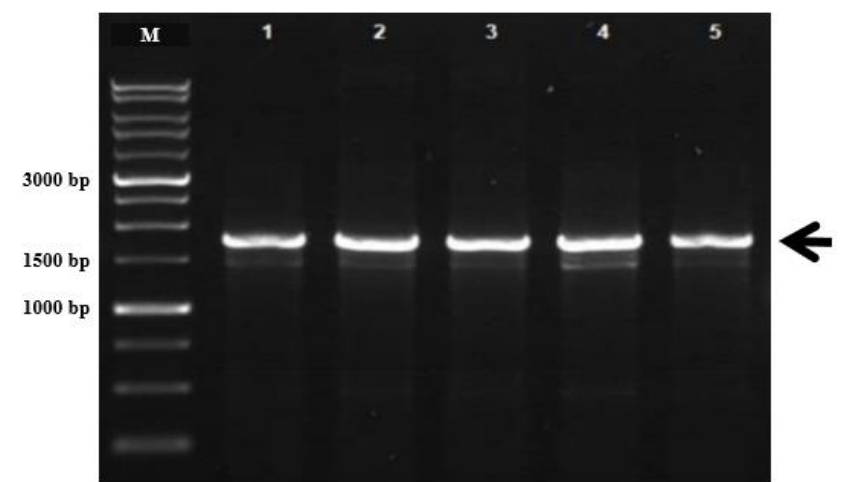

Figure 4. Visualization of the iaa M gene $( \pm 1698 \mathrm{bp}$, arrowhead) of Streptomyces isolates on $1 \%$ agarose gel. (M) marker, (1) S. panaciradicis ARK 13, (2) S. tritolerans ARK 17, (3) S. recifensis ARK 63, (4) S. tendae ARK 91, and (5) S. manipurensis ARK 94

Table 1. The growth inhibition of F. oxysporum by Streptomyces isolates on PDA after seven days of incubation.

\begin{tabular}{lc}
\hline Isolates & Growth inhibition $(\boldsymbol{\%}) \pm$ SD \\
\hline S. panaciradicis ARK 13 & $51 \pm 0.00$ \\
S. tritolerans ARK 17 & $41 \pm 2.10$ \\
S. recifensis ARK 63 & $52 \pm 1.11$ \\
S. tendae ARK 91 & $45 \pm 7.55$ \\
S. manipurensis ARK 94 & $76 \pm 2.10$ \\
\hline
\end{tabular}

Table 2. The IAA production of Streptomyces isolates on molasses culture medium with the addition of L-tryptophan $0.2 \%$

\begin{tabular}{lc}
\hline Isolates & $\begin{array}{c}\text { IAA concentration } \\
\left(\mathbf{m g ~ L}^{-1}\right) \pm \text { SD }\end{array}$ \\
\hline S. panaciradicis ARK 13 & $12.25 \pm 0.64$ \\
S. tritolerans ARK 17 & $13.39 \pm 0.23$ \\
S. recifensis ARK 63 & $08.99 \pm 0.23$ \\
S. tendae ARK 91 & $15.14 \pm 0.14$ \\
S. manipurensis ARK 94 & $13.44 \pm 0.18$ \\
Bradyrhizobium japonicum (control) & $16.24 \pm 0.05$ \\
\hline
\end{tabular}

Table 3. Phosphate solubilization index of Streptomyces isolates on Pikovskaya medium incubated for seven days.

\begin{tabular}{lc}
\hline Isolates & $\begin{array}{c}\text { Phosphate solubilization index } \\
\mathbf{\pm} \text { SD }\end{array}$ \\
\hline S. panaciradicis ARK 13 & $2.43 \pm 0.19$ \\
S. tritolerans ARK 17 & $2.23 \pm 0.09$ \\
S. recifensis ARK 63 & $2.13 \pm 0.31$ \\
S. tendae ARK 91 & $2.33 \pm 0.05$ \\
S. manipurensis ARK 94 & $2.47 \pm 0.09$ \\
\hline
\end{tabular}

Table 4. The diversity of iaaM genes of Streptomyces isolates by BLASTX.

\begin{tabular}{llccc}
\hline Isolates & Homology & Query & $\begin{array}{c}\text { Similarity } \\
(\%)\end{array}$ & $\begin{array}{c}\text { Accession } \\
\text { number }\end{array}$ \\
\hline S. panaciradicis ARK 13 & Tryptophan 2-monooxygenase [S. paradoxus] & 99 & 95.1 & MBB6078269.1 \\
S. tritolerans ARK 17 & Tryptophan 2-monooxygenase [Streptomyces sp. MH60] & 96 & 85.5 & PPS84631.1 \\
S. recifensis ARK 63 & Tryptophan 2-monooxygenase [Streptomyces sp. 2221.1] & 95 & 96.6 & REH19738.1 \\
S. tendae ARK 91 & Tryptophan 2-monooxygenase [Streptomyces sp. BK208] & 95 & 96.1 & TDT36864.1 \\
S. manipurensis ARK 94 & Tryptophan 2-monooxygenase [Streptomyces sp. SLBN-109] & 99 & 94.5 & TQK33573.1 \\
\hline
\end{tabular}




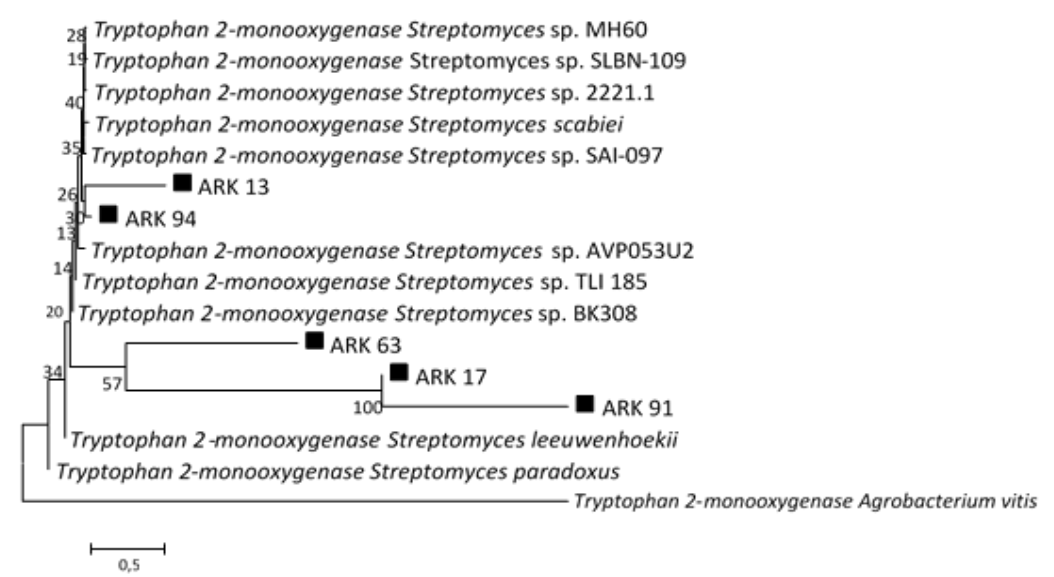

Figure 5. Phylogenetic tree showing the relationship between the five Streptomyces isolates tryptophan-2-monooxygenase with the comparison species using the Neighbor-Joining method based on the iaaM gene sequence. The black box was the Streptomyces isolate used. The number 0.5 showed the kinship scale. Tryptophan-2-monooxygenase Agrobacterium vitis was used as the outgroup

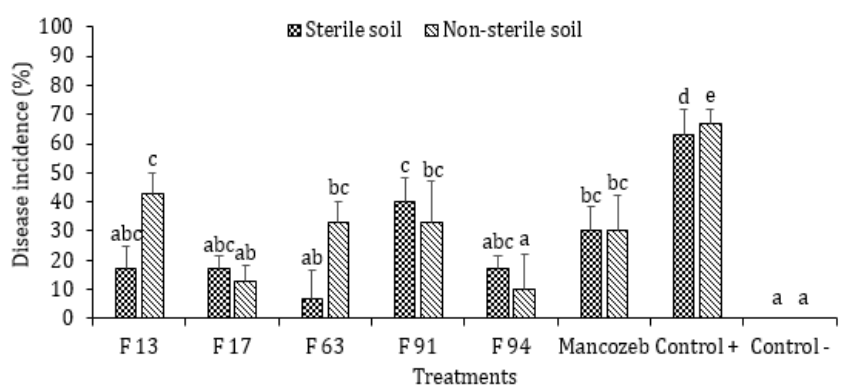

Figure 6. The percentage of disease incidence caused by $F$. oxysporum in each treatment.

\section{The viability of Streptomyces formulas}

Five Streptomyces formulas were able to maintain viability at week 8 with an average of $10^{8} \mathrm{CFU} \mathrm{g}^{-1}$. The highest concentration was found at F91, which was $10 \mathrm{x}$ $10^{8} \mathrm{CFU} \mathrm{\textrm {g } ^ { - 1 }}$. Meanwhile, the lowest concentration was found at F13, which was $5 \times 10^{7} \mathrm{CFU} \mathrm{g}^{-1}$. The moisture content of each formula stored at room temperature varied from $44 \%$ to $52 \%$. The highest water content was at F13 and the lowest water content was at F94. The measurement of $\mathrm{pH}$ was also carried out for each type of Streptomyces formula. All the formulas had a $\mathrm{pH}$ of 7 .

\section{Application of Streptomyces formulas on soybean plant}

Fusarium oxysporum infestation caused rot of root, hypocotyl, cotyledon, and damping-off in soybean plants. The results of statistical tests showed that the five Streptomyces formulas reduced disease incidence and increase disease suppression significantly in soybean plants. The lowest disease incidence (7\%) was found in F63 in sterile soil and F94 (10\%) in non-sterile soil (Figure 6). The highest disease suppression was found in F63 (89\%) in sterile soil and F94 (85\%) in non-sterile soil (Figure 7). Four formulas (F13, F17, F63, and F94) on sterile soil and two formulas (F17 and F94) on non-sterile soil were able to decrease disease incidence and increase disease incidence better than synthetic fungicide Mancozeb, and significantly increased soybean plant growth (Table 5). F17 and F94 were the best

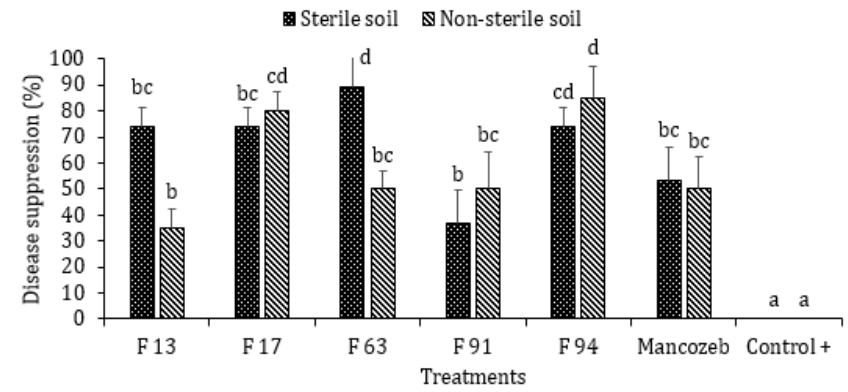

Figure 7. The percentage of disease suppression in each treatment

formulas for suppressing pathogenic fungal disease of $F$. oxysporum and increasing soybean growth.

Table 5. The growth of seven-day-old soybean plants in sterile and non-sterile soil infested with $F$. oxysporum.

\begin{tabular}{|c|c|c|c|c|}
\hline \multirow[b]{2}{*}{ Treatments } & \multicolumn{4}{|c|}{ Growth parameters } \\
\hline & $\begin{array}{l}\text { Root length } \\
\text { (cm) }\end{array}$ & $\begin{array}{l}\text { Plant length } \\
\text { (cm) }\end{array}$ & $\begin{array}{l}\text { Wet weight } \\
\text { (g) }\end{array}$ & $\begin{array}{c}\text { Dry weight } \\
\text { (g) }\end{array}$ \\
\hline \multicolumn{5}{|l|}{ Sterile soil } \\
\hline Control + & $3.44 \mathrm{ab}$ & $7.83 \mathrm{ab}$ & $0.60 \mathrm{ab}$ & $0.09 \mathrm{ab}$ \\
\hline Control - & $4.92 \mathrm{a}$ & $10.67 \mathrm{a}$ & $0.71 \mathrm{a}$ & $0.11 \mathrm{a}$ \\
\hline $\mathrm{F} 13$ & $8.92 \mathrm{~cd}^{*}$ & $14.31 \mathrm{c}^{*}$ & $1.22 \mathrm{c}^{*}$ & $0.22 c^{*}$ \\
\hline F17 & $8.63 \mathrm{bcd}$ & $13.21 \mathrm{bc}$ & $1.24 \mathrm{c}^{*}$ & $0.27 \mathrm{c}^{*}$ \\
\hline F63 & $8.42 \mathrm{bcd}$ & $13.55 \mathrm{bc}$ & $0.90 \mathrm{abc}$ & $0.17 \mathrm{abc}$ \\
\hline F91 & $9.34 \mathrm{~d}^{*}$ & $13.47 \mathrm{bc}$ & $1.17 \mathrm{c}^{*}$ & $0.20 \mathrm{bc}$ \\
\hline F94 & $8.98 \mathrm{~cd}^{*}$ & $13.96 c^{*}$ & $1.11 \mathrm{bc}$ & $0.17 \mathrm{abc}$ \\
\hline Mancozeb & $5.17 \mathrm{abc}$ & $11.59 \mathrm{bc}$ & $0.93 \mathrm{abc}$ & $0.16 a b c$ \\
\hline \multicolumn{5}{|c|}{ Non-sterile soil } \\
\hline Control + & $2.96 \mathrm{a}$ & $9.13 \mathrm{a}$ & $0.49 \mathrm{a}$ & $0.12 \mathrm{a}$ \\
\hline Control - & $3.42 \mathrm{ab}$ & $10.21 \mathrm{ab}$ & $0.65 \mathrm{ab}$ & $0.11 \mathrm{a}$ \\
\hline F13 & $5.25 \mathrm{ab}$ & $13.71 \mathrm{bc}$ & $0.82 \mathrm{bc}$ & $0.15 a b$ \\
\hline F17 & $6.38 \mathrm{~b}$ & $14.84 \mathrm{c}^{*}$ & $1.15 \mathrm{~d}^{*}$ & $0.25 b^{*}$ \\
\hline F63 & $5.63 \mathrm{ab}$ & $12.84 \mathrm{bc}$ & $0.90 \mathrm{bc}$ & $0.15 \mathrm{ab}$ \\
\hline F91 & $5.30 \mathrm{ab}$ & $13.13 \mathrm{bc}$ & $0.90 \mathrm{bcd}$ & $0.15 \mathrm{ab}$ \\
\hline F94 & $6.21 \mathrm{~b}$ & $14.75 \mathrm{c}^{*}$ & $0.99 \mathrm{~cd}^{*}$ & $0.14 \mathrm{ab}$ \\
\hline Mancozeb & $5.17 \mathrm{ab}$ & $10.78 a b c$ & $0.81 \mathrm{bc}$ & $0.11 \mathrm{a}$ \\
\hline
\end{tabular}

Note: *: The growth parameters were significantly increased and different than the negative control at the $95 \%$ confidence level 


\section{Discussion}

Five Streptomyces isolates were successfully cultured on alternative growth media. Streptomyces was chemoorganotrophic which could grow on various types of carbon sources, including monosaccharides, disaccharides, polysaccharides, polyols, and various organic acids (Sousa et al. 2016). The results showed that molasses medium could produce higher cell biomass of Streptomyces. The molasses was a byproduct of the sugar cane processing into sugar. The molasses contain $90 \%$ sucrose and $10 \%$ glucose (Basso et al. 2011). Sucrose was a disaccharide from the monomers glucose and fructose which could be used by Streptomyces as a carbon source. The simpler carbon sources in molasses can be used more easily by Streptomyces compared to starch as the more complex carbon sources in potato broth and bran extract growth media. The addition of yeast extract as a source of organic nitrogen was also reported to affect the cell biomass production of Streptomyces. Saurav et al. (2010) reported that the addition of organic nitrogen sources such as yeast to culture media yield relatively high cell biomass of Streptomyces. The use of molasses as a growing medium increased the productivity of antimicrobial compounds in Streptomyces cyaneus DN 37 (Abdelwahed et al. 2012). It indicates that the molasses medium might be used as a growth medium for the production of Streptomyces biomass.

The optimum incubation time in the molasses medium was similar to the ISP4 media (day 5th and 7th). Streptomyces biomass reaches its optimum weight under optimal conditions for mycelium formation. The life cycle of Streptomyces starts in an exponential phase when the spores germinate into vegetative hyphae then grow to form branched hyphae or vegetative hyphae. The decrease in biomass that occurred on the 9th day might be due to decreased nutrients in the media. In nutrient deficiency conditions, vegetative hyphae was autolysis degraded by cell death mechanism to form aerial hypha, and antibiotics were produced in this phase (Barka et al. 2016).

The growth of $F$. oxysporum, as opposed to Streptomyces, was inhibited without direct contact. This suggests that the five isolates grown on molasses media could still inhibit the growth of the pathogenic fungi $F$. oxysporum. It indicated that Streptomyces produced bioactive compounds that might have anti-fungal activity and cell wall degrading enzymes. Microscopic observations showed the presence of lysis and granulation of $F$. oxysporum hyphae. Streptomyces indiaensis SRT1 produces secondary metabolites as an antifungal which inhibits spore germination, hyphal segmentation, and distortion in spores of $F$. oxysporum NCIM 1072 (Bhosle et al. 2018). The chitinase enzyme produced by $S$. griseorubens $\mathrm{E} 44 \mathrm{G}$ from soil could inhibit $F$. oxysporum which causes wilt on tomatoes (Rashad et al. 2017). Streptomyces spororaveus RDS28 grown on simple carbon source media could produce optimal antifungal compounds capable of inhibiting the growth of Rhizoctonia solani, $F$. solani, F. verticillioides, Alternia alternata, and Botrytis cinerea (Al-Askar et al. 2011).
The detection of the iia $\mathrm{M}$ gene in five isolates indicated that these isolates might be able to produce IAA using the indole-3 acetamide (IAM) pathway. Two enzymes play a role in the IAM pathway, namely tryptophan-2monooxygenase and indole-3-acetamide hydrolase. The former enzyme converts the amino acid tryptophan into intermediate IAM and the later enzyme hydrolyzed IAM into IAA. Based on the results of BLASTX, the iaaM genes in five isolates had a similarity level of $85.5 \%$ to 96.6\% with tryptophan-2-monooxygenase Streptomyces spp. The result confirmed the result of the previous study, that five isolates were able to produce IAA hormone and increase the growth of soybean plants in vitro (Wahyudi et al. 2019). Several previous studies reported that the Streptomyces spp. have been known to have the gene encoding iaaM. Passari et al. (2016) reported that Streptomyces spp. associated with tomatoes has the iaaM gene. Generally, rhizobacteria were able to synthesize IAA through the IAM pathway (Zhang et al. 2019).

Five isolates were able to produce IAA in molasses medium with the addition of L-tryptophan $0.2 \%$. Supplementation of $0.2 \%$ L-tryptophan in the growth media was aimed to get the optimum condition for the production of IAA by $S$. fradiae NKZ-259 (Myo et al. 2019). The difference in IAA production of five Streptomyces in this study could be caused by differences in the metabolic ability of the isolate to convert Ltryptophan to IAA. A previous study by Wahyudi et al. (2019) showed that IAA production of Streptomyces from soybean rhizosphere cultured on media with simple carbon, organic nitrogen, and the addition of $0.2 \%$ L-tryptophan was in the range of 2.08 to $16.70 \mathrm{mg} \mathrm{L}^{-1}$. It was assumed that five Streptomyces isolates were able to produce IAA in molasses growth medium.

All of the isolates were able to solubilize phosphate in Pikovskaya media with $\mathrm{Ca}_{3}\left(\mathrm{PO}_{4}\right)$ as the phosphate source. These isolates might produce organic acids which are capable of chelating $\mathrm{Ca}$ from $\mathrm{Ca}_{3}\left(\mathrm{PO}_{4}\right)$. A study by Farried et al (2018) showed that Streptomyces spp. isolated from the rhizosphere could produce organic acids that solubilize phosphate with the solubilizing index of 1.57 to 3.83 . Streptomyces isolated from wheat roots produced malic acid which can solubilize phosphate and increased wheat growth (Jog et al. 2014).

The Streptomyces formulas were able to maintain viability with the population density of $10^{8} \mathrm{CFU} \mathrm{g}^{-1}$ at 8 weeks and water content of $44 \%$ to $52 \%$. The bacteria in bacterial formula with peat carrier material survives up to 180 days with a population density of $10^{8} \mathrm{CFU} \mathrm{\textrm {g } ^ { - 1 }}$ (Khabbaz and Abbasi 2014). Water content also affects the survival of microbes in the peat carrying material by $40 \%$ to $50 \%$ (Casteriano et al. 2013).

Formulas of F17 and F94 could significantly suppress the disease caused by $F$. oxysporum and promote the growth of soybean plants. Streptomyces suppresses disease incidence by antibiotic mechanisms, hyperparasitism, produce various bioactive compounds and enzymes that degrade fungal cell walls (Khalil et al. 2014). The formulated cells of $S$. griseus could inhibit the growth of $F$. oxysporum f.sp. cubense on sterile soil (Zacky and Ting 
2015). Streptomyces ma. Fs-4 could reduce the disease incidence caused by Fusarium and increase banana growth (Duan et al. 2020). The powder formulation of $S$. corchorusii strain UCR3-16 also increases growth significantly in rice (Tamreihao et al. 2016).

Based on the results of the study, the Streptomyces formulas with the peat carrying material can maintain viability up to 8 weeks with a population density of $10^{8}$ $\mathrm{CFU} \mathrm{g}^{-1}$ at room temperature. Formulas F17 and F94 were the best formulas to control disease caused by $F$. oxysporum with the disease suppression of $74 \%$ in sterile soil and $80-85 \%$ in non-sterile soil. These formulas also significantly increased the growth of soybean plants in sterile and non-sterile soils in the greenhouse experiment.

\section{ACKNOWLEDGEMENTS}

Part of this work was funded by The Ministry of Research and Technology/ National Research and Innovation Agency of The Republic of Indonesia in 2020, and partly was funded in 2021 through "Penelitian DasarUnggulan Perguruan Tinggi” (PD-UPT) to ATW (Contract No. 1/E1/KP.PTNBH/2020; and No. 1/E1/KP.PTNBH/2021). Therefore, we thank and appreciate all the supports given to carry out this research.

\section{REFERENCES}

Abdelwahed NAM, Abdallah NA, El-Ghawas DE, El-Din SMB, ElDiwany AI. 2012. Isolation, identification and optimization of antimicrobial metabolites produced by soil-derived actinomycetes. Egypt J Exp Biol 8 (2): 205-217.

Al-Askar AA, Abdulaziz KMW, Rashad YM. 2011. In vitro antifungal activity of Streptomyces spororaveus RDS28 against some phytopathogenic fungi. Afr J Agri Res 6 (12): 2835-2842.

Arias MMD, Leandro LF, Munkvold GP. 2013. Aggressiveness of Fusarium species and impact of root infection on growth and yield of soybeans. Ecol Epidemiol 8 (103): 822-832. DOI: 10.1094/phyto-0812-0207-r.

Arias MMD, Munkvold GP, Ellis ML, Leandro LES. 2013. Distribution and frequency of Fusarium species associated with soybean roots in Iowa. Plant Dis 97: 1157-1562. DOI: 10.1094/PDIS-11-12-1059-RE.

Arora NK, Mishra J. 2016. Prospecting the roles of metabolites and additives in future bioformulations for sustainable agriculture. Appl Soil Ecol 107: 405-407. DOI: 10.1016/j.apsoil.2016.05.020.

Barka EA, Vatsa P, Sanchez L, Gaveau-Vaillant N, Jacquard C, Klenk HP, Clément C, Ouhdouch Y, Wezel GP. 2016. Taxonomy, physiology, and natural products of actinobacteria. Microbiol Mol Biol Rev 80: 1 43. DOI: 10.1128/MMBR.00019-15.

Basso LC, Basso TO, Rocha SN. 2011. Ethanol production in Brazil: the industrial process and its impact on yeast fermentation. Biofuel ProdRec Dev Pros 1530: 85-100. DOI: 10.5772/17047.

Bhosle HJ, Kadam TA, Mirajgave RS, Holkar SK. 2018. Optimization and characterization of antifungal metabolite from a soil actinomycete Streptomyces indiaensis SRT. Indian J Biotechnol 17 (2): 261-271.

Casteriano A, Wilkes MA, Deaker R. 2013. Physiological changes in rhizobia after growth in peat extract may be related to improved desiccation tolerance. Appl and Environ Microbiol 79 (13): 3998 4007. DOI: 10.1128/AEM.00082-13.

Cui J, Wang Y, Han J, Cai B. 2016. Analyses of the community compositions of root rot pathogenic fungi in the soybean rhizosphere soil. Chil J Agr Res 76 (2): 179-187. DOI: 10.4067/S071858392016000200007.

Duan Y, Chen J, He W, Chen J, Pang Z, Hu H, Xie J. 2020. Fermentation optimization and disease suppression ability of a Streptomyces ma.
FS-4 from banana rhizosphere soil. BMC Microbiol 20 (24): 1-12. DOI: 10.1186/s12866-019-1688-z.

Ellis ML, Arias MMD, Jimenez DRC, Munkvold GP, Leandro LF. 2013. First report of Fusarium commune causing damping-off, seed rot, and seedling root rot on soybean (Glycine max) in the United States. Plant Dis 97 (2): 284. DOI: 10.1094/PDIS-07-12-0644-PDN.

Farried, Al-Shaimaa M, Mohamed HM, El-Dsouky, El-Rewainy HM. 2018. Isolation and characterization of phosphate solubilizing actinomycetes from rhizosphere soil. Assiut J Agric Sci 49 (4): 125137.

Glick BR. 2012. Plant growth-promoting bacteria: mechanisms and applications. Scientifica. DOI: 10.6064/2012/963401.

Gopalakrishnan S, Pande S, Sharma M, Humayun P, Kiran BK, Sandeep D, Vidya MS, Deepthi K, Rupela O. 2011. Evaluation of actinomycete isolates obtained from herbal vermicompost for the biological control of Fusarium wilt of chickpea. Crop Prot 30 (8): 1070-1078. DOI: 10.1016/j.cropro.2011.03.006.

Gopalakrishnan S, Sathya A, Vijayabharathi R, Srinivas V. 2016. Formulation of plant growth-promoting microbes for field applications. Microb Inocul Sustain Agric Product 15: 239-251. DOI: 10.1007/978-81-322-2644-4_15

Husnain SK, Khan SB, Atiq M, Rajput NA, Abbas W, Mohsin M. 2019. Screening of peas (Pisum sativum) varieties/ lines against fusarium wilt (Fusarium oxysporum f. sp. Pisi) and in vitro evaluation of fungicides against mycelial growth of pathogen. Pak J Phtopathol 31 (1): 89-96. DOI: 10.33866/phytopathol.031.01.0492.

Jog R, Pandya M, Narshkumar G, Rajkumar S. 2014. Mechanism of phosphate solubilization and antifungal activity of Streptomyces spp. isolated from wheat roots and rhizosphere and their application in improving plant growth. Microbiology 160: 778-788. DOI: 10.1099/mic.0.074146-0.

Khabbaz SE, Abbasi PA. 2014. Isolation, characterization, and formulation of antagonistic bacteria for the management of seedlings damping-off and root rot disease of cucumber. Can J Microbiol 60 (1): 25-33. DOI: 10.1139/cjm-2013-0675.

Khalil MS, Moubasher H, Hasan FF. 2014. Biological control of rice blast disease by Streptomyces flavotricini. Res J Pharm Biol Chem Sci 5: 1453-1461.

Khamna S, Yokota A, Peberdy JF, Lumyong S. 2010. Indole-3-acetic acid production by Streptomyces sp. isolated from Thai medicinal plant rhizosphere soils. EurAsia J BioSci 4: 23-32. DOI: 10.5053/ejobios.2010.4.0.4.

Khare A, Singh BK, Upadhyay RS. 2010. Biological control of Pythium aphanidermatum causing damping-off of mustard by mutants of Trichoderma viridae 1433. J Agric Technol 6: 231-243.

Lin $\mathrm{L}, \mathrm{Xu} \mathrm{X}$. 2013. Indole-3-acetic acid production by endophytic Streptomyces sp. En-1 isolated from medical plants. Curr Microbiol. 67: 209-217. DOI: 10.1007/s00284-013-0348-z.

Maier M, Souza CA, Casa RT. 2018. Cropping systems on root rot and soybean seed yield. Ciência Rural 48 (7): 1-8. DOI: 10.1590/0103$8478 \mathrm{cr} 20170460$

Mariastuti HD, Listiyowati S, Wahyudi AT. 2018. Antifungal activity of soybean rhizosphere actinomycetes producing bioactive compounds against Fusarium oxysporum. Biodiversitas 19 (6): 2127-2133. DOI: 10.13057/biodiv/d190619.

Myo EM, Ge B, Ma J, Cui H, Liu B, Shi L, Jiang M, Zhang K. 2019. Indole-3-acetic acid production by Streptomyces fradiae NKZ-259 and its formulation to enhance plant growth. BMC Microbiol 19 (155): $1-14$

Olanrewaju OS, Babalola OO. 2019. Streptomyces: implications and interactions in plant growth promotion. Appl Microbiol Biotechnol 103: 1179-1188. DOI: 10.1007/s00253-018-09577-y.

Passari AK, Chandra P, Zothanpuia, Mishra VK, Leo VV, Gupta VK, Kumar B, Singh BP. 2016. Detection of biosynthetic gene and phytohormone production by endophytic actinobacteria associated with Solanum lycopersicum and their plant-growth-promoting effect. Res Microbiol 167 (8): 692-705. DOI: 10.1016/j.resmic.2016.07.001.

Rajeswari P. 2015. Control of Fusarium oxysporum causing fusarium wilt by Trichoderma spp and Pseudomonas fluorescens on Arachis hypogaea L. Int J Adv Biotechnol Res 6: 57-65.

Rashad, Younes, Al-Askar, Abdulaziz, Ghoneem, Khalid, Ali S, Wesameldin, Hafez, Elsayed. 2017. Chitinolytic Streptomyces griseorubens E44G enhances the biocontrol efficacy against Fusarium wilt disease of tomato. Phytoparasitica 45 (2): 227-237. DOI: 10.1007/s12600-017-0580-3. 
Sadeghi A, Karimi E, Dahaji PA, Javid MG, Dalvand Y, Askari H. 2012. Plant growth promoting activity of an auxin and siderophore producing isolate of Streptomyces under saline soil conditions. World J Microbiol Biotechnol 28: 1503-1509. DOI: 10.1007/s11274-0110952-7.

Saurav K, Kannabiran K. 2010. Diversity and optimization of process parameters for the growth of Streptomyces VITSVK9 spp. isolated from Bay of Bengal, India. J Nat Env Sci 1 (2): 56-65.

Sousa JADJ, Olivares FL. 2016. Plant growth promotion by Streptomycetes: Ecophysiology, mechanisms and applications. Chem and Biol Technol Agric 3 (24): 1-12. DOI: 10.1186/s40538-0160073-5.

Tamreihao K, Ningthoujam DS, Nimaichand S, Singh ES, Reena P, Singh SH, Nongthomba U. 2016. Biocontrol and plant growth promoting activities of a Streptomyces corchorusii strain UCR3-16 and preparation of powder formulation for application as biofertilizer agents for rice plant. Microbiol Res 192: 260-270. DOI: 10.1016/j.micres.2016.08.005

Wahyudi AT, Priyanto JA, Afrista R, Kurniati D, Astuti RI, Akhdiya A. 2019. Plant growth promoting activity of actinomycetes isolated from soybean rhizosphere. Online J Biol Sci 19 (1): 1-8. DOI: 10.3844/ojbsci.2019.1.8.

Zacky FA, Ting ASY. 2015. Biocontrol of Fusarium oxysporum f.sp. cubense tropical race 4 by formulated cells and cell-free extracts of Streptomyces griseus in sterile soil environment. Biocontrol Sci Technol 25 (6): 685-696. DOI: 10.1080/09583157.2015.1007921.

Zhang P, Jin T, Kumar Sahu S, Xu J, Shi Q, Liu H, Wang Y. 2019. The distribution of tryptophan-dependent indole-3-acetic acid synthesis pathways in bacteria unraveled by large-scale genomic analysis. Molecules 24 (7): 1-14. DOI: 10.3390/molecules2407141. 